\title{
Pengaruh Penerapan Problem Based Learning (PBL) dan Project Based Learning (PjBL) Terhadap Kemampuan Pemecahan Masalah Berdasarkan Self Efficacy Siswa
}

\author{
Resdiana Safithri, Syaiful ${ }^{2}$, Nizlel Huda ${ }^{3}$ \\ 1, 2,3 Program Studi Pendidikan Matematika, Fakultas Pascasarjana, Universitas Jambi \\ Jl. Raden Mattaher No.16-Jambi, Kota Jambi, Indonesia \\ resdianasafithri@gmail.com
}

\begin{abstract}
Pandemic Covid-19 has made learning process become online learning. Teachers must keep develop their student's problem's solving ability. PBL and PjBL with Zoom Cloud Meeting application make students construct their ideas to solve mathematics problems. This study aimed to see differences of student's problem's solving ability that taught by PBL and PjBL based on self efficacy. The research design used was quasi experimental non-equivalent control group design, population are the students in class XI SMA N 5 Jambi and simple random sampling as a sampling technique that obtained 2 experiment class, 1 control class. The instruments used was test, questionnaires, observation sheets. From the result of the study with two way's ANOVA test, it was concluded that there are differences of student's problem's solving ability that taught PBL and PjBL, but there is no interaction between PBL and PjBL with self efficacy on student's problem's solving ability. This is because, something that is owned by each individual student before being given treatment and learning methods by the teacher has no interaction with students' mathematical problem's solving abilities, because students already have confidence (self-efficacy) in each of them to solve a problem before given teaching material with a learning method.
\end{abstract}

Keywords: Online Learning, PBL, PjBL, Problem Solving Ability, Self Efficacy

\begin{abstract}
Abstrak
Pandemi COVID-19 mengakibatkan pembelajaran dilaksanakan secara daring, guru tetap mengembangkan kemampuan pemecahan masalah siswa. PBL dan PjBL dilaksanakan dengan aplikasi Zoom Cloud Meeting membuat siswa dapat mengkonstruksi ide penyelesaian masalah. Tujuan penelitian untuk melihat perbedaan kemampuan pemecahan masalah siswa yang diajarkan dengan PBL dan PjBL secara daring berdasarkan self efficacy, melihat interaksi antara pembelajaran PBL, PjBL, self efficacy terhadap kemampuan pemecahan masalah siswa. Desain penelitian menggunakan quasi experimental non-equivalent control group design, dengan populasi seluruh siswa kelas XI IPA SMA N 5 Kota Jambi, dengan teknik pengambilan sampel yaitu simple random sampling didapat 2 kelas eksperimen dan 1 kelas kontrol. Instrumen penelitian yaitu tes, angket, dan lembar observasi. Hasil penelitian diuji dengan ANOVA dua arah, menunjukan terdapat perbedaan kemampuan pemecahan masalah siswa yang memiliki self efficacy tinggi, sedang, rendah yang diajarkan dengan PBL dan PjBL, namun tidak terdapat iteraksi antara pembelajaran PBL dan PjBL dengan self efficacy siswa terhadap kemampuan pemecahan masalah. Hal ini dikarenakan, sesuatu yang telah dimiliki oleh setiap individu siswa sebelum diberikan perlakuan dan metode pembelajaran oleh guru tidak ada interaksi nya terhadap kemampuan pemecahan masalah matematika siswa, karena siswa sudah memiliki keyakinan (self efficacy) didalam dirinya masing-masing untuk menyelesaikan suatu masalah sebelum diberi materi ajar dengan suatu metode pembelajaran.
\end{abstract}

Kata kunci: Pembelajaram Daring, PBL, PjBL, Kemampuan Pemecahan Masalah, Self Efficacy

Copyright (c) 2021 Resdiana Safithri, Syaiful, Nizlel Huda

$\triangle$ Corresponding author: Resdiana Safithri

Email Address: resdianasafithri@gmail.com (J1. Raden Mattaher No.16-Jambi, Kota Jambi, Indonesia)

Received 03 Maret 2021, Accepted 05 Maret 2021, Published 06 Maret 2021

\section{PENDAHULUAN}

Pendidikan memiliki peranan yang sangat penting dalam kehidupan manusia. Tanpa disadari semua aktivitas manusia berhubungan erat dengan pendidikan. Bangsa yang maju adalah bangsa yang memiliki sumber daya manusia yang berkualitas, baik dari segi spiritualitas, kecerdasan, juga keterampilan. Salah satu hal yang dapat dilakukan untuk dapat mencapai tujuan tersebut yaitu 
pembaharuan secara terus menerus dalam bidang pendidikan, khususnya pada mata pelajaran matematika. Matematika merupakan ilmu dasar yang digunakan untuk mengembangkan cabang ilmu lain.

Pembelajaran matematika sudah mulai diajarkan sejak pendidikan dasar hingga ke perguruan tinggi, hal tersebut dilakukan agar mampu menghasilkan sumber daya manusia yang siap untuk menghadapi perkembangan ilmu pengetahuan dan teknologi yang terus berkembang dengan sangat cepat, sehingga akan menghasilkan individu yang memiliki kemampuan memperoleh, mengelola, dan juga memanfaatkan informasi dan teknologi yang akan digunakan untuk bertahan hidup ditengah perkembangan zaman saat ini. Salah satu visi pembelajaran matematika Indonesia adalah pendidikan matematika untuk memahami konsep dan gagasan matematika yang nantinya akan diterapkan ke dalam pemecahan masalah rutin dan non-rutin melalui penalaran, komunikasi, dan koneksi dalam matematika dan juga diluar matematika itu sendiri (Fitriani et al., 2017).

Kemampuan pemecahan masalah merupakan kemampuan siswa dalam menyelesaikan masalah matematika dengan mengamati proses dalam menemukan jawaban berdasarkan langkah-langkah pemecahan masalah, yakni memahami masalah, merencanakan pemecahan masalah, memecahkan masalah, dan mengecek ulang (Havill \& Havill, 2020). Meskipun matematika merupakan mata pelajaran yang sangat penting dalam dunia pendidikan dan sangat banyak kaitannya dalam kehidupan sehari-hari, namun matematika masih saja dianggap sebagai momok yang menakutkan bagi siswa. Siswa cenderung takut dan merasa kesulitan dalam belajar matematika, umumnya pada masalah matematika yang dibuat sedemikan kompleks, sehingga siswa kesulitan untuk memecahkan masalah matematika, yang berakibat rendahnya kemampuan pemecahan masalah matematis siswa, adapun rendahnya kemampuan pemecahan masalah matematika siswa disebabkan oleh siswa mengalami kesulitan dalam memahami masalah matematika yang mempengaruhi proses pemecahan masalah (Bayuningsih et al., 2017).

Meskipun saat ini, pembelajaran dilaksanakan secara daring agar dapat memutus mata rantai penyebaran virus Covid-19, guru dituntut untuk melaksanakan pembelajaran secara daring. Pembelajaran daring yaitu proses belajar mengajar yang dilaksanakan dengan menggunakan jaringan internet dari jarak jauh dengan aksesibilitas, konektivitas, fleksibilitas, dan kemampuan untuk menimbulkan interaksi pembelajaran yang dilaksanakan dari jarak jauh (Nadeak, 2020).

Salah satu strategi yang dapat dilakukan guru untuk mengoptimalkan kemampuan pemecahan masalah matematika siswa dalam melaksanakan pembelajaran matematika secara daring adalah model pembelajaran. Siswa dipandang sebagai makhluk yang aktif dan mempunyai kemampuan untuk mengembangkan dirinya, dengan model pembelajaran konstruktivisme. Problem Based Learning (PBL) adalah salah satu model pembelajaran berbasis konstruktivisme (Nurlaeli et al., 2018).

PBL merupakan model pembelajaran yang mengutamakan penggunaan masalah actual sebagai konteks bagi siswa untuk belajar berpikir kritis dan keterampilan pemecahan masalah serta memperoleh konsep dan pengetahuan esensial dari pelajaran lain (Suharini \& Handoyo, 2020). 
Dengan menerapkan PBL secara daring pada dalam pembelajaran matematika berbantu media akan memperkuat kemampuan pemecahan masalah dan karakter mandiri siswa, sehingga siswa mampu merumuskan, menyelesaikan dan menafsirkan mateatika dalam berbagai konteks (Tambunan et al., 2018). Selain problem based learning (PBL), pembelajaran project based learning (PjBL) juga dapat menjadi salah satu solusi bagi guru untuk mendukung kemampuan pemecahan masalah siswa. PjBL adalah pembelajaran yang berpusat pada siswa yang melibatkan siswa dalam mengkonstruksi pengetahuannya dengan eksplorasi masalah otentik dan melakukan tugas yang dirancang dengan baik (Serin, 2019).

Terdapat keterkaitan antara PBL dengan PjBL dalam memecahkan masalah matematika, yakni PBL berfokus pada solving real world sedangkan PjBL berfokus pada membangun atau menciptakan sebuah konsep dari sebuah masalah otentik (Mahendra, 2017). Kesuksesan pelaksanaan suatu model pembelajaran juga dapat dipengaruhi oleh karakteristik siswa, salah satunya adalah self efficacy.

Salah satu aspek yang harus dimiliki individu setiap siswa agar dapat memecahkan masalah matematika adalah kondisi mental siswa, kepercayaan diri siswa (self efficacy) terhadap kemampuan yang dimiliki terutama tentang matematika dan pemecahan masalah matematika menentukan keberhasilan siswa dalam memecahkan masalah matematika (Ulandari et al., 2019). Menurut Bandura (1997), Self efficacy merupakan kepercayaan diri siswa terhadap kemampuannya yang dapat berpengaruh terhadap kemampuan pemecahan masalah matematis siswa. Dalam pembelajaran matematika, self efficacy diartikan sebagai kepercayaan diri individu tentang menyelesaikan berbagai tugas, dari memahami konsep hingga memecahkan masalah matematika (Masitoh \& Fitriyani, 2018).

Adapun tujuan dari penelitian ini yakni untuk mengetahui apakah terdapat perbedaan kemampuan pemecahan masalah siswa yang memiliki self efficacy tinggi, sedang, dan rendah yang diajarkan dengan PBL dan PjBL, dan untuk mengetahui apakah terdapat interaksi antara pembelajaran PBL, PjBL, dan self efficacy siswa terhadap kemampuan pemecahan masalah siswa.

\section{METODE}

Metode yang digunakan pada penelitian ini adalah quasi-experiment research. Penelitian quasiexperimental adalah desain penelitian dimana individu tidak ditempatkan dalam kelompok sepenuhnya secara acak (Creswell, 2012). Desain dalam penelitian ini yaitu nonequivalent control group design, dimana terdapat kelompok eksperimen dan kontrol yang akan diberi pretest untuk mengetahui keadaan awal tiap kelompok yang diberi perlakuan adapun desain penelitian akan ditampilkan pada tabel 1 .

Tabel 1. Desain Penelitian

\begin{tabular}{|c|c|c|c|}
\hline Kelas & Pretest & Perlakuan & Posttest \\
\hline Eksperimen I (PBL) & $\mathrm{O}_{1 \mathrm{~A}}$ & $\mathrm{X}_{\mathrm{A}}$ & $\mathrm{O}_{2 \mathrm{~A}}$ \\
\hline Eksperimen II (PjBL) & $\mathrm{O}_{1 \mathrm{~B}}$ & $\mathrm{X}_{\mathrm{B}}$ & $\mathrm{O}_{2 \mathrm{~B}}$ \\
\hline Kontrol (Konvensional) & $\mathrm{O}_{1 \mathrm{C}}$ & $\mathrm{X}_{\mathrm{C}}$ & $\mathrm{O}_{2 \mathrm{C}}$ \\
\hline
\end{tabular}


Ket :

$\mathrm{O}_{1 \mathrm{~A}} \quad=$ Tes awal $($ Pretest $)$ pada kelas eksperimen $\mathrm{I}$

$\mathrm{O}_{1 \mathrm{~B}} \quad=$ Tes awal $($ Pretest $)$ pada kelas eksperimen II

$\mathrm{O}_{1 \mathrm{C}} \quad=$ Tes awal (Pretest) pada kelas kontrol

$\mathrm{O}_{2 \mathrm{~A}} \quad=$ Tes akhir (Posttest) pada kelas eksperimen I

$\mathrm{O}_{1 \mathrm{~B}} \quad=$ Tes akhir (Posttest) pada kelas eksperimen II

$\mathrm{O}_{1 \mathrm{C}} \quad=$ Tes akhir (Posttest) pada kelas kontrol

$\mathrm{X}_{\mathrm{A}} \quad=$ Perlakuan pembelajaran PBL secara daring

$\mathrm{X}_{\mathrm{B}} \quad=$ Perlakuan pembelajaran PjBL secara daring

$\mathrm{X}_{\mathrm{C}} \quad=$ Perlakuan pembelajaran konvensional secara daring

Penelitian dilaksanakan pada tanggal 11 januari - 11 februari di SMA N 5 Kota Jambi. Adapun populasi penelitian ini adalah seluruh siswa kelas XI SMA N 5 Kota Jambi dengan sampel kelas XI IPA 1 sebagai kelas eksperimen I, kelas XI IPA 2 sebagai kelas eksperimen II, dan kelas XI IPA 4 sebagai kelas kontrol.

Instrumen yang digunakan dalam penelitian ini yaitu, instrument angket self efficacy, pretest dan posttest kemampuan pemecahan masalah matematika, dan lembar observasi keterlaksanaan pembelajaran siswa dan guru. Siswa diberikang angket self efficacy sebelum memluai pembelajaran dan sebelum dilaksanakan pretest, setelah diberikan angket self efficacy, siswa diberikan soal pretest yang berisi materi prasyarat dari materi yang akan diajarkan.

Setelah diberikan pretest, siswa diberi perlakuan dengan Kelas eksperimen I akan diberikan pembelajaran dengan metode PBL, kelas eksperimen II diberikan pembelajaran dengan metode PjBL, sedangkan kelas kontrol diberikan pembelajaran konvensional, adapun semua proses pembelajaran dilaksanakan secara daring dengan aplikasi Zoom Cloud Meeting. Setelah itu, masing-masing kelas diberi posttest kemampuan pemecahan masalah terkait materi barisan dan deret yang telah diajarkan. Kemudian data diuji dengan uji ANOVA dua arah yang digunakan untuk mengetahui apakah terdapat interaksi antara penerapan pembelajaran $\mathrm{PBL}$ dan $\mathrm{PjBL}$ dengan self efficacy siswa terhadap kemampuan pemecahan masalah siswa, setelah itu dilakukan uji lanjut Tukey untuk melihat berapa besar perbedaan perlakuan dan self efficacy terhadap kemampuan berpikir kritis siswa.

\section{HASIL DAN DISKUSI}

\section{Hasil}

Sebelum dilaksanakan pembelajaran PBL dan PjBL, siswa diberi angket self efficacy untuk melihat kategori self efficacy masing-masing siswa di kelas eksperimen dan kelas kontrol. Setelah dilakukan analisis terhadap angket self efficacy siswa, didapat bahwa pada kelas eksperimen I terdapat 4 orang siswa dengan kategori self efficacy tinggi, 24 siswa dengan self efficacy kategori sedang, dan 
3 orang siswa dengan kategori rendah. Pada kelas eksperimen II terdapat 10 orang siswa dengan kategori self efficacy tinggi, 19 siswa dengan kategori self efficacy sedang, dan 2 siswa dengan kategori self efficacy rendah, sedangkan pada kelas kontrol terdapat 5 siswa dengan kategori tinggi, 15 siswa kategori sedang, dan 12 siswa dengan self efficacy kategori rendah.

Setelah diberikan angket, siswa diberi pretest untuk melihat kemampuan awal siswa. Setelah dilakukan analisis pada hasil pretest siswa. Untuk analisis lebih lanjut, dilakukan uji normalitas dan homogenitas pada hasil pretest siswa. Adapun hasil uji normalitas data pretest siswa dapat dilihat pada tabel 2, dan uji homogenitas data pretest siswa dapat dilihat pada tabel 3.

Tabel 2. Uji normalitas data pretest siswa

\begin{tabular}{|l|r|r|r|}
\hline & \multicolumn{3}{|c|}{ Shapiro-Wilk } \\
\cline { 2 - 4 } & Statistic & \multicolumn{1}{|c|}{ Df } & \multicolumn{1}{c|}{ Sig. } \\
\hline Kelas Eksperimen I & 0.97 & 31 & 0.73 \\
\hline Kelas Eksperimen II & 0.96 & 31 & .0 .33 \\
\hline Kelas Kontrol & 0.95 & 31 & 0.26 \\
\hline
\end{tabular}

Tabel 3. Uji homogenitas data pretest siswa

\begin{tabular}{|c|c|c|c|}
\hline Levene Statistic & df1 & df2 & Sig. \\
\hline 140 & 2 & 91 & 0.86 \\
\hline
\end{tabular}

Pada tabel 2. dapat dilihat bahwa untuk kelas eksperimen I, kelas eksperimen II, dan kelas kontrol, nilai signifikansi nya lebih dari 0.05. Maka dapat disimpulkan bahwa data nilai pretest untuk kelas eksperimen I, kelas eksperimen II, dan kelas kontrol berdistribusi normal. Selanjutnya, pada tabel 3. Dapat dilihat bahwa nilai signifikansinya lebih dari 0.05 maka data nilai pretest siswa memiliki variansi yang sama atau homogen.

Setelah dilakukan pretest, masing-masing kelas diberikan perlakuan berupa pembelajaran PBL secara daring pada kelas eksperimen I, pembelajaran $\mathrm{PjBL}$ secara daring pada kelas eksperimen II, dan pembelajaran konvensional secara daring pada kelas kontrol. Siswa diberikan perlakuan yang sama (tidak terdapat perbedaan perlakuan antara siswa yang memiliki self efficacy tinggi, sedang, dan rendah). Keterlaksanaan aktivitas peneliti dan siswa diamati oleh guru menggunakan lembar observasi.

Setelah diberi perlakuan pada kelas eksperimen dan kelas kontrol, siswa diberi posttest sesuai indikator kemampuan pemecahan masalah. Tes yang diberikan pun sama (tidak terdapat perbedaan perlakuan antara siswa yang memiliki self efficacy tinggi, sedang, dan rendah). Dilakukan uji normalitas dan homogenitas pada hasil posttest siswa. Adapun hasil uji normalitas data posttest siswa dapat dilihat pada tabel 4, dan uji homogenitas data pretest siswa dapat dilihat pada tabel 5. 
Tabel 4. Uji normalitas data posttest siswa

\begin{tabular}{|l|c|c|c|}
\hline \multirow{2}{*}{} & \multicolumn{3}{|c|}{ Shapiro-Wilk } \\
\cline { 2 - 4 } & Statistic & df & Sig. \\
\hline Kelas Eksperimen I & 0.95 & 31 & 0.17 \\
\hline Kelas Eksperimen II & 0.95 & 31 & 0.25 \\
\hline Kelas Kontrol & 0.95 & 31 & 0.17 \\
\hline
\end{tabular}

Tabel 5. Uji homogenitas data posttest siswa

\begin{tabular}{|c|c|c|c|}
\hline Levene Statistic & df1 & df2 & Sig. \\
\hline 0.43 & 2 & 91 & 0.64 \\
\hline
\end{tabular}

Pada tabel 4. Dapat dilihat bahwa pada kelas eksperimen I (pembelajaran PBL), kelas eksperimen II (pembelajaran PjBL), dan kelas kontrol (pembelajaran konvensional) memperoleh nilai signifikansi yang lebih dari 0.05 . Maka dapat disimpulkan bahwa data nilai posttest untuk kelas eksperimen I, kelas eksperimen II, dan kelas kontrol berdistribusi normal. Selanjutnya, pada tabel 5. Dapat dilihat bahwa nilai signifikansinya yakni lebih dari 0.05 maka data nilai posttest siswa memiliki variansi yang sama atau homogen.

Setelah dipenuhi asumsi untuk uji hipotesis, dilakukan uji hipotesis. Hipotesis diuji dengan uji Two Way ANOVA serta uji lanjut tukey untuk melihat perbedaan yang signifkan pada masing-masing variabel, yakni metode pembelajaran terhadap kemampuan pemecahan masalah siswa dan self efficacy terhadap kemampuan pemecahan masalah siswa. Hasil pengujian hipotesis menggunakan uji Two Way ANOVA dapat dilihat pada tabel 6 berikut ini.

Tabel 6. Uji Two Way ANOVA

\begin{tabular}{|l|r|r|r|}
\hline \multicolumn{1}{|c|}{ Source } & Type III Sum of Squares & \multicolumn{1}{c|}{ F } & \multicolumn{1}{l|}{ Sig. } \\
\hline $\begin{array}{l}\text { Corrected } \\
\text { Model }\end{array}$ & $15325.800^{\mathrm{a}}$ & 26.608 & .000 \\
\hline Intercept & 278675.825 & 3870.53 & .000 \\
\hline Metode & 3604.021 & 25.028 & .000 \\
\hline SE & 3116.874 & 21.645 & .000 \\
\hline Metode * SE & 495.225 & 1.720 & .153 \\
\hline Error & 6119.945 & & \\
\hline Total & 547200.000 & & \\
\hline $\begin{array}{l}\text { Corrected } \\
\text { Total }\end{array}$ & 21445.745 & 93 & \\
\hline
\end{tabular}

Pada tabel 6. Dapat dilihat bahwa nilai signifikansi untuk metode pembelajaran adalah 0.00 yakni kurang dari 0.05, maka dapat disimpulkan bahwa terdapat pengaruh penerapan pembelajaran PBL dan PjBL terhadap kemampuan pemecahan masalah siswa. Dapat dilihat juga juga bahwa nilai signifikansi untuk self efficacy siswa adalah 0.00 yakni kurang dari 0.05 , maka dapat disimpulkan juga bahwa terdapat pengaruh self efficacy siswa terhadap kemampuan pemecahan masalah siswa. 
Pengaruh Penerapan Problem Based Learning (PBL) dan Project Based Learning (PjBL) Terhadap Kemampuan Pemecahan Masalah Berdasarkan Self Efficacy Siswa, Resdiana Safithri, Syaiful, Nizlel Huda

Selanjutnya dapat dilihat pada nilai signifikansi untuk metode dan self efficacy adalah 0.153 yakni lebih dari 0.05, maka dapat disimpulkan tidak terdapat interaksi penerapan pembelajaran PBL dan PjBL serta self efficacy siswa terhadap kemampuan pemecahan masalah siswa.

Untuk melihat besarnya perbedaan perlakuan dan self efficacy siswa terhadap kemampuan pemecahan masalah siswa dilakukan uji lanjut (tukey). Hasil uji lanjut tukey untuk variabel metode pembelajaran dapat dilihat pada tabel 7 berikut ini:

Tabel 7. Uji lanjut Tukey variabel metode pembelajaran

\begin{tabular}{|l|l|r|r|r|r|r|}
\hline \multirow{3}{*}{$(\mathbf{I})$ Kelas } & \multirow{2}{*}{$\begin{array}{c}\text { Mean } \\
\text { Difference }\end{array}$} & \multirow{2}{*}{$\begin{array}{c}\text { Std. } \\
\text { Error }\end{array}$} & \multirow{2}{*}{ Sig. } & & \multicolumn{2}{|c|}{$\begin{array}{c}\text { 95\% Confidence } \\
\text { Interval }\end{array}$} \\
\cline { 3 - 7 } & & & & $\begin{array}{l}\text { Lower } \\
\text { Bound }\end{array}$ & $\begin{array}{l}\text { Upper } \\
\text { Bound }\end{array}$ \\
\hline \multirow{2}{*}{ PBL } & PjBL & -3.55 & 2.155 & .232 & -8.69 & 1.59 \\
\cline { 2 - 7 } & Konvensional & $19.70^{*}$ & 2.138 & .000 & 14.60 & 24.80 \\
\hline \multirow{2}{*}{ PjBL } & PBL & 3.55 & 2.155 & .232 & -1.59 & 8.69 \\
\cline { 2 - 7 } & Konvensional & $23.25^{*}$ & 2.138 & .000 & 18.15 & 28.35 \\
\hline \multirow{2}{*}{ Konvensional } & PBL & $-19.70^{*}$ & 2.138 & .000 & -24.80 & -14.60 \\
\cline { 2 - 7 } & PjBL & $-23.25^{*}$ & 2.138 & .000 & -28.35 & -18.15 \\
\hline
\end{tabular}

Pada tabel 7. Dapat dilihat bahwa kemampuan pemecahan masalah siswa yang diajarkan dengan pembelajaran PjBL lebih besar 3,55 poin daripada kemampuan pemecahan masalah siswa yang diajarkan dengan pembelajaran PBL. Kemampuan pemecahan masalah siswa yang diajarkan dengan pembelajaran PBL lebih besar 19,70 poin daripada kemampuan berpikir pemecahan masalah siswa yang diajarkan dengan pembelajaran konvensional. Serta kemampuan pemecahan masalah siswa yang diajarkan dengan pembelajaran PjBL lebih besar 23.25 poin daripada kemampuan pemecahan masalah siswa yang diajarkan dengan pembelajaran konvensional.

Selanjutnya dilakukan uji lanjut Tukey untuk variabel self efficacy terhadap kemampuan pemecahan masalah siswa, hasil uji lanjut Tukey dapat dilihat pada tabel 8 berikut ini:

Tabel 8. Uji lanjut Tukey variabel self efficacy

\begin{tabular}{|c|c|c|c|c|c|c|}
\hline \multirow{2}{*}{$\begin{array}{c}\text { (I) } \\
\text { Kemampunan } \\
\text { Awal }\end{array}$} & \multirow{2}{*}{$\begin{array}{c}(\mathbf{J}) \\
\text { Kemampunan } \\
\text { Awal }\end{array}$} & \multirow{2}{*}{$\begin{array}{c}\text { Mean } \\
\text { Difference } \\
(\mathbf{I}-J)\end{array}$} & \multirow{2}{*}{$\begin{array}{l}\text { Std. } \\
\text { Error }\end{array}$} & \multirow{2}{*}{ Sig. } & \multicolumn{2}{|c|}{$\begin{array}{l}\text { 95\% Confidence } \\
\text { Interval } \\
\end{array}$} \\
\hline & & & & & $\begin{array}{l}\text { Lower } \\
\text { Bound }\end{array}$ & $\begin{array}{l}\text { Upper } \\
\text { Bound }\end{array}$ \\
\hline \multirow{2}{*}{ Tinggi } & Sedang & $11.77^{*}$ & 2.243 & .00 & 6.42 & 17.12 \\
\hline & Rendah & $32.31^{*}$ & 2.833 & .00 & 25.55 & 39.06 \\
\hline \multirow{2}{*}{ Sedang } & Tinggi & $-11.77^{*}$ & 2.243 & .00 & -17.12 & -6.42 \\
\hline & Rendah & $20.53^{*}$ & 2.340 & .00 & 14.95 & 26.11 \\
\hline \multirow{2}{*}{ Rendah } & Tinggi & $-32.31^{*}$ & 2.833 & .00 & -39.06 & -25.55 \\
\hline & Sedang & $-20.53^{*}$ & 2.340 & .00 & -26.11 & -14.95 \\
\hline
\end{tabular}

Pada tabel 8. Dapat dilihat bahwa kemampuan pemecahan masalah siswa dengan self efficacy tinggi lebih besar 11.77 poin daripada kemampuan pemecahan masalah siswa dengan self efficacy 
sedang. kemampuan pemecahan masalah siswa dengan self efficacy tinggi lebih besar 32.31 poin daripada kemampuan pemecahan masalah siswa dengan self efficacy rendah. Serta kemampuan kemampuan pemecahan masalah siswa dengan self efficacy sedang lebih besar 20.53 poin daripada kemampuan pemecahan masalah siswa dengan self efficacy rendah.

\section{Diskusi}

\section{Pengaruh Pembelajaran Online PBL dan PjBL Terhadap Kemampuan Pemecahan Masalah}

Berdasarkan hasil ANOVA dua jalur yang telah dilakukan terhadap hasil posttes kemampuan pemecahan masalah siswa kelas XI MIA1, XI MIA 2, dan XI MIA 4 setelah diajarkan dengan pembelajaran PBL, PjBL, dan pembelajaran konvensional secara daring didapatkan hasil bahwa $\mathrm{H}_{0}$ diterima. Nilai signifikansinya adalah $0,00(<0,05)$, dengan kata lain terdapat pengaruh penerapan pembelajaran PBL dan PjBL terhadap kemampuan pemecahan masalah siswa. Dengan demikian penerapan model PBL dan model PjBL sama sama berpengaruh terhadap kemampuan pemecahan masalah matematika siswa.

Hal ini sesuai dengan pendapat Siregar et al (2018), yang menyatakan bahwa penerapan model PBL dapat memperbaiki kemampuan pemecahan masalah siswa, sehingga siswa dapat menilai kemampuan nya sendiri dalam memecahkan masalah menjadi lebih baik karena pada model PBL ini siswa harus mencari solusi dan mereka juga akan dilatih untuk memecahkan masalah, dimana masalah yang dihadirkan dalam proses pembelajaran mencerminkan masalah nyata yang dihadapi dalam kehidupan sehari-hari.

Menurut Serin (2019), penerapan PjBL dalam proses pembelajaran memberikan siswa kesempatan untuk membangun pengetahuan dalam konteks nyata, dimana ide utama dalam PjBL adalah memberi kesempatan pada siswa untuk menyelidiki masalah dalam dunia nyata yang akan memungkinkan siswa memperoleh pengetahuan baru, PjBL memberikan kesempatan siswa untuk mengeksplor kemampuannya dalam hal berpikir kritis, pemecahan masalah, dan juga kerja mandiri. Oleh karena itu, meningkatkan kemampuan pemecahan masalah siswa sangatlah penting dalam pembelajaran matematika agar tercapai tujuan pembelajaran dengan baik.

Penelitian terdahulu terkait kemampuan pemecahan masalah telah banyak dilakukan, diantaranya penelitian yang dilakukan oleh Ulva et al (2020) terkait penerapan PBL terhadap kemampuan pemecahan masalah, hasil penelitiannya adalah kemampuan pemecaahan masalah siswa yang diajarkan dengan model PBL lebih baik daripada siswa yang diajarkan dengan pembelajaran konvensional. Penelitian yang dilakukan oleh Masri et al (2018) mendapatkan hasil bahwa peningkatan kemampuan pemecahan masalah siswa yang diajarkan dengan PBL lebih tinggi daripada siswa yang diajarkan dengan pembelajaran konvensional. Berdasarkan penelitian yang dilakukan oleh Fiana et al (2019) membuktikan bahwa terdapat pengaruh positif dari pembelajaran PjBL terhadap kemampuan pemecahan masalah siswa.

Berdasarkan hasil uji lanjut tukey terhadap pembelajaran PBL, PjBL, dan konvensional pada 
penelitian ini didapat bahwa, kemampuan pemecahan masalah siswa yang diajarkan dengan $\mathrm{PjBL}$ lebih besar 3,55 poin daripada kemampuan pemecahan masalah siswa yang diajarkan dengan PBL. Hal ini dikarenakan pada pembelajaran PjBL siswa mampu merekonstruksi kemampuannya dalam memecahkan masalah sendiri dari proyek yang diberikan guru berupa soal pemecahan masalah sehingga mereka dapat menemukan sendiri konsep dari materi yang diajarkan.

Berdasarkan hasil uji lanjut tukey juga didapat bahwa, kemampuan pemecahan masalah siswa yang diajarkan dengan PBL lebih besar 19,70 poin daripada kemampuan pemecahan masalah siswa yang diajarkan dengan pembelajaran konvensional. Sedangkan kemampuan pemecahan masalah siswa yang diajarkan dengan PjBL lebih besar 23,25 poin daripada kemampuan pemecahan masalah siswa yang diajarkan dengan Konvensional.

\section{Pengaruh Self Efficacy Siswa Terhadap Kemampuan Pemecahan Masalah}

Berdasarkan hasil ANOVA dua jalur yang telah dilakukan terhadap hasil posttes kemampuan pemecahan masalah siswa kelas XI MIA1, XI MIA 2, dan XI MIA 4 setelah diajarkan dengan pembelajaran PBL, PjBL, dan pembelajaran konvensional secara daring didapatkan hasil bahwa $\mathrm{H}_{0}$ diterima. Nilai signifikansinya adalah $0,00(<0,05)$, maka maka $\mathrm{H}_{0}$ ditolak, yang artinya terdapat perbedaan kemampuan pemecahan masalah yang signifikan ditinjau dari siswa yang memiliki self efficacy tinggi, sedang, dan rendah. Berdasarkan perhitungan statistika deskriptif untuk masingmasing kelompok, rata-rata skor kemampuan pemecahan masalah siswa yang memiliki self efficacy tinggi lebih baik dibanding siswa dengan self efficacy sedang dan rendah. Dengan demikian, self efficacy memiliki pengaruh yang signifikan terhadap kemampuan pemecahan masalah siswa.

Penelitian yang telah dilakukan oleh Somawati (2018) mendapatkan hasil bahwa terdapat pengaruh yang signifikan antara self efficacy terhadap pemecahan masalah matematika, yang artinya dalam menyelesaikan masalah matematika, semakin tinggi self efficacy siswa maka semakin mudah menyelesaikan masalah matematika. Berdasarkan penelitian yang telah dilakukan oleh Utami \& Wutsqa (2017), siswa dengan self efficacy yang tinggi akan berhubungan dengan prestasi matematika yang tinggi pula, baik dari segi berpikir kritis dan memecahkan masalah.

Berdasarkan hasil uji lanjut tukey didapat bahwa kemampuan pemecahan masalah siswa yang memiliki self efficacy tinggi lebih besar 11,77 poin daripada kemampuan pemecahan masalah siswa dengan self efficacy sedang. Untuk kemampuan pemecahan masalah siswa yang memiliki self efficacy tinggi lebih besar 32,31 poin daripada kemampuan pemecahan masalah siswa dengan self efficacy rendah, sedangkan kemampuan pemecahan masalah siswa yang memiliki self efficacy sedang lebih besar 20,53 poin daripada kemampuan pemecahan masalah siswa dengan self efficacy rendah. Hal ini didukung oleh pernyataan Pajares \& Kranzler (1995) bahwa self efficacy memberikan dasar untuk memotivasi, bertindak baik, dan berprestasi dalam semua bidang kehidupan. 


\section{Interaksi Antara Pembelajaran Online PBL dab PjBL serta Self Efficacy Siswa Terhadap Kemampuan Pemecahan Masalah}

Berdasarkan hasil ANOVA dua jalur yang telah dilakukan terhadap hasil posttest kemampuan pemecahan masalah siswa dan hasil self efficacy siswa pada kelas eksperimen I, kelas eksperimen II, dan juga kelas kontrol, didapat hasil bahwa $\mathrm{H}_{0}$ diterima, yakni tidak terdapat interaksi antara penerapan pembelajaran PBL dan PjBL dengan self efficacy siswa terhadap kemampuan pemecahan masalah siswa. Hal ini dikarenakan self efficacy merupakan faktor internal dalam yang sudah dimiliki siswa sebelum diberikan perlakuan dalam menyelesaikan segala hambatan yang ada dalam dirinya.

Hal ini sama dengan penelitian yang telah dilakukan oleh Endah et al (2019) yang hasil penelitiannya adalah tidak terdapat interaksi antara model pembelajaran LAPS-heuristic dan konvensional dan juga self efficacy terhadap kemampuan pemecahan masalah matematika siswa. Selanjutnya dalam penelitian Destiniar et al (2019) yang hasil penelitiannya yaitu tidak terdapat interaksi antara model pembelajaran Think Pair Share dan self efficacy siswa terhadap kemampuan pemahaman konsep matematis siswa kelas VII SMP N 20 Palembang. Berdasarkan penelitian yang telah dilakukan oleh Hasyim \& Eldiana (2020) yang menyatakan bahwa hal yang dimiliki oleh masing-masing siswa sebelum diberi perlakuan dan model pembelajaran tidak ada interaksi terhadap kemampuan pemecahan masalah matematika siswa.

\section{KESIMPULAN}

Berdasarkan hasil dan pembahasan yang telah dijelaskan, dapat disimpulkan bahwa: (1) terdapat pengaruh penerapan pembelajaran PBL dan PjBL terhadap kemampuan pemecahan masalah siswa, (2) terdapat pengaruh self efficacy siswa terhadap kemampuan pemecahan masalah siswa, dan (3) tidak terdapat interaksi antara penerapan pembelajaran PBL, PjBL dan pembelajaran konvensional secara daring dengan self efficacy siswa terhadap kemampuan pemecahan masalah siswa. Hal ini dikarenakan sesuatu yang telah dimiliki oleh masing-masing siswa didalam diri nya sebelum diberikan perlakuan dan metode pembelajaran oleh guru tidak ada interaksi terhadap kemampuan pemecahan masalah matematika siswa.

Hasil penelitian ini merekomendasikan agar guru menggunakan pembelajaran PBL dan PjBL untuk mengembangkan kemampuan pemecahan masalah siswa dalam pembelajaran daring di masa pandemi saat ini. Namun, guru juga harus memastikan sarana dan prasarana yang akan digunakan saat pembelajaran secara daring tersedia dengan baik dan stabil baik untuk siswa maupun untuk guru sendiri. Serta guru juga harus memperhatikan kondisi kelas pada saat pembelajaran, seperti siswa harus mengaktifkan mode video pada saat pembelajaran dengan Zoom Cloud Meeting.

\section{UCAPAN TERIMA KASIH}

Peneliti mengucapkan rasa syukur kepada Allah SWT.karena selalu diberikan kelancaran dalam menyelesaikan artikel ini. Peneliti juga mengucapkan terima kasih kepada orangtua, suami dan 
anak, serta keluarga yang telah memberi dukungan penuh kepada peneliti. Rasa terima kasih juga peneliti ucapkan kepada pembimbing saya yakni Dr. Syaiful, M.Pd. dan Dr. Nizlel Huda, M. Kes. yang telah memberi bimbingan dan arahan dalam menyelesaikan penelitian dan artikel ini. Terakhir, rasa terima kasih ini peneliti ucapkan kepada sahabat-sahabat saya yang selalu memberi dukungan dan semangat.

\section{REFERENSI}

Bandura, A. (1997). Theoretical Perspectives: the nature of human agency. In Self-efficacy: The exercise of control (p. http://search.ebscohost.com/login.aspx?direct=true \&db=a9h\&AN=9703260522\&site=ehost-live

Bayuningsih, A. S., Usodo, B., \& Subanti, S. (2017). Analysis of Junior High School Students' Problem-solving Ability Reviewed from Self-regulated Learning. International Journal of Science and Applied Science: Conference Series, 2(1), 51. https://doi.org/10.20961/ijsascs.v2i1.16678

Creswell. (2012). Educational Research. Pearson Education Inc.

Destiniar, D., Jumroh, J., \& Sari, D. M. (2019). Kemampuan Pemahaman Konsep Matematis Ditinjau Dari Self Efficacy Siswa Dan Model Pembelajaran Think Pair Share (Tps) Di Smp Negeri 20 Palembang. Jurnal Penelitian Dan Pembelajaran Matematika, $12(1)$. https://doi.org/10.30870/jppm.v12i1.4859

Endah, D. R. J., Kesumawati, N., \& Andinasari, A. (2019). Kemampuan Pemecahan Masalah Matematis Berdasarkan Self Efficacy Siswa Melalui Logan Avenue Problem Solving-Heuristic.

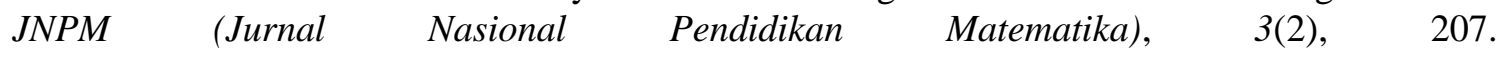
https://doi.org/10.33603/jnpm.v3i2.2331

Fiana, R. O., Relmasira, S. C., \& Hardini, A. T. A. (2019). Perbedaan Penerapan Model Project Based Learning Dan Problem Based Learning Terhadap Hasil Belajar Matematika Kelas 4 Sd. Jurnal Basicedu, 3(1), 157-162. https://doi.org/10.31004/basicedu.v3i1.108

Fitriani, Surya, E., \& Saragih, S. (2017). Peningkatan Kemampuan Pemecahan Masalah dan Komunikasi Matematik Siswa SMP Negeri Langkat Yang Diajarkan Model Problem Centered Learning. $10(2)$

$150-164$. https://jurnal.unimed.ac.id/2012/index.php/paradikma/article/view/8696/7502

Hasyim, M., \& Eldiana, N. F. (2020). Eksperimentasi model PBL dan PjBL berbasis schoology terhadap pemecahan masalah matematika ditinjau dari self-efficacy. JP2M (Jurnal Pendidikan Dan Pembelajaran Matematika), 6(2), 87. https://doi.org/10.29100/jp2m.v6i2.1751

Havill, J., \& Havill, J. (2020). How to Solve It. In Discovering Computer Science. https://doi.org/10.1201/9781003037149-1

Mahendra, I. W. E. (2017). Project Based Learning Bermuatan Etnomatematika Dalam Pembelajar Matematika. JPI (Jurnal Pendidikan Indonesia), 6(1), 106-114. https://doi.org/10.23887/jpiundiksha.v6i1.9257

Masitoh, L. F., \& Fitriyani, H. (2018). Improving students' mathematics self-efficacy through problem based learning. Malikussaleh Journal of Mathematics Learning (MJML), 1(1), 26. https://doi.org/10.29103/mjml.v1i1.679

Masri, M. F., Suyono, S., \& Deniyanti, P. (2018). Pengaruh Metode Pembelajaran Berbasis Masalah Terhadap Self-Efficacy Dan Kemampuan Pemecahan Masalah Matematis Ditinjau Dari 
Kemampuan Awal Matematika Siswa Sma. Jurnal Penelitian Dan Pembelajaran Matematika, 11(1). https://doi.org/10.30870/jppm.v11i1.2990

Nadeak, B. (2020). The effectiveness of distance learning using social media during the pandemic period of covid-19: A case in universitas kristen indonesia. International Journal of Advanced Science and Technology, 29(7), 1764-1772. https://www.scopus.com/inward/record.uri?partnerID=HzOxMe3b\&scp=85085285142\&origin= inward

Nurlaeli, N., Noornia, A., \& Wiraningsih, E. D. (2018). Pengaruh Model Pembelajaran Problem Based Learning Terhadap Kemampuan Berpikir Kritis Matematis Siswa Ditinjau Dari Adversity Quotient. FIBONACCI: Jurnal Pendidikan Matematika Dan Matematika, 4(2), 145. https://doi.org/10.24853/fbc.4.2.145-154

Pajares, F., \& Kranzler, J. (1995). Role of self-efficacy and general mental ability in mathematical problem solving: A path analysis. Annual Meeting of the American Educational Research Association, 1986, 3-33.

Serin, H. (2019). Project Based Learning in Mathematics Context. International Journal of Social Sciences \& Educational Studies, 5(3), 232-236. https://doi.org/10.23918/ijsses.v5i3p232

Siregar, N., Asmin, D., \& Fauzi, K. M. A. (2018). The Effect of Problem Based Learning Model on Problem Solving Ability Student. January. https://doi.org/10.2991/aisteel-18.2018.100

Somawati, S. (2018). Peran Efikasi Diri (Self Efficacy) terhadap Kemampuan Pemecahan Masalah Matematika. Jurnal Konseling Dan Pendidikan, 6(1), 39. https://doi.org/10.29210/118800

Suharini, E., \& Handoyo, E. (2020). Effectiveness of Problem Based Learning Model Assisted by Pocket Book toward Student Self-Efficacy. 29(10), 1199-1204.

Tambunan, L., Rusdi, R., \& Miarsyah, M. (2018). Efectiveness of Problem Based Learning Models by Using E-Learning and Learning Motivation Toward Students Learning Outcomes on Subject Circullation Systems. Indonesian Journal of Science and Education, 2(1), 96. https://doi.org/10.31002/ijose.v2i1.598

Ulandari, L., Amry, Z., \& Saragih, S. (2019). Development of Learning Materials Based on Realistic Mathematics Education Approach to Improve Students' Mathematical Problem Solving Ability and Self-Efficacy. International Electronic Journal of Mathematics Education, 14(2), 375-383. https://doi.org/10.29333/iejme/5721

Ulva, E., Maimunah, \& Murni, A. (2020). Pengaruh Model Problem Based Learning Terhadap Kemampuan Pemecahan Masalah Matematis Siswa Kelas VII SMPN Se-Kabupaten Kuantan Singingi Pada Materi Aritmetika Sosial. Jurnal Cendekia: Jurnal Pendidikan Matematika, 4(1), $1230-1238$.

Utami, R. W., \& Wutsqa, D. U. (2017). Analisis kemampuan pemecahan masalah matematika dan self-efficacy siswa SMP negeri di Kabupaten Ciamis. Jurnal Riset Pendidikan Matematika, 4(2), 166. https://doi.org/10.21831/jrpm.v4i2.14897 